\title{
The management of persistent pulmonary hypertension of the newborn: A review
}

\author{
L G Lloyd, MB ChB, DCH (SA), FC Paed (SA), MMed (Paed), Cert Neonatology (SA); \\ J Smith, MB ChB, MMed, FC Paed (SA), PhD (Paed)
}

Division of Neonatology, Department of Paediatrics and Child Health, Stellenbosch University and Tygerberg Children's Hospital, Cape Town, South Africa

Corresponding author: L G Lloyd (lgl@sun.ac.za)

\begin{abstract}
Persistent pulmonary hypertension of the newborn is a neonatal emergency with a high mortality rate in spite of several advances in the management thereof. The underlying pathophysiology is complex and multifactorial. The gold standard of treatment is inhaled nitric oxide, yet up to a third of patients will not respond to standard treatment. This article reviews treatment modalities available, as well as the evidence to support the use of these treatment options.
\end{abstract}

S Afr J Child Health 2016;10(4):194-198. DOI:10.7196/SAJCH.2016.v10i4.1145

The first literary reference to persistent pulmonary hypertension (PH) of the newborn (PPHN) can be found in 1969 by Gersony et al. ${ }^{[1,2]}$ who described it as persistence of physiologic characteristics of the fetal circulation in the absence of disease. Defined as a failure of normal circulatory transition at birth, or more specifically as failure of the pulmonary vasculature to relax after birth, with continued shunting of non-oxygenated blood into the systemic circulation via fetal channels (ductus arteriosus and foramen ovale), it remains a challenging neonatal emergency to manage. ${ }^{[3-6]}$ Term and nearterm infants are most commonly affected, but PPHN can occur in premature infants. ${ }^{[4]}$

The incidence of PPHN in developed countries has been estimated as 1.9 per 1000 live births; however, the incidence is likely to be higher in developing countries. ${ }^{[2,3,5,7]}$ PPHN constitutes $\sim 10 \%$ of neonatal intensive care unit (NICU) admissions, with the reported mortality rate ranging from 10 to $20 \% .^{[4,5,8-10]}$

\section{Physiology}

The normal physiological state of a fetus is best described as hypoxaemic, with $\mathrm{PH}$ and reduced pulmonary blood flow, and with the placenta responsible for gas and nutrient exchange. ${ }^{[3,4,6,10]}$ It is important to understand that the fetus is not hypoxic, as adequate oxygen delivery to the tissues is maintained and facilitated by a high cardiac output and high fetal haemoglobin levels with increased oxygen affinity. ${ }^{[3]}$

Factors involved in maintaining an increased pulmonary vascular resistance (PVR) in utero include fluid-filled lungs, decreased nitric oxide (NO) and prostacyclin $\left(\mathrm{PGI}_{2}\right)$, and increased endothelin-1 (ET-1). ${ }^{[4]}$ Products of the prostaglandin pathway, such as thromboxane and leukotriene, also play a role. Serotonin increases fetal PVR, which brings into question the safety of using selective serotonin reuptake inhibitors (SSRIs) during pregnancy. ${ }^{[3,4,6,11]}$

\section{Fetal circulation}

The systemic and pulmonary circulations of the fetus function in parallel, where both ventricles essentially eject blood into the aorta and use the foramen ovale and ductus arteriosus to bypass the pulmonary circulation. Only $13-25 \%$ of blood ejected will reach pulmonary circulation. ${ }^{[3,4,6,11]}$

\section{Transition to extrauterine life}

The normal transition from 'parallel' to 'series' circulation starts with a rapid decrease in PVR with the first breath, and an increase in systemic vascular resistance with the removal of the low-resistance placenta after umbilical cord clamping. ${ }^{[3,10]}$ The first breath fills the lungs with air, causing an eight-fold increase in pulmonary blood flow. The resulting shear stress and oxygenation up-regulates the expression of endothelial NO synthase (eNOS). ${ }^{[3,4,6]}$ Endothelial NO synthesised from l-arginine activates soluble guanylyl cyclase (sGC), converting cyclic guanosine triphosphate (cGTP) to cyclic guanosine monophosphate (cGMP), which facilitates smooth muscle relaxation. ${ }^{[4-6]}$ Oxygenation also inhibits phosphodiesterase-5 (PDE5), increasing the availability of cGMP. ${ }^{[4]}$

The production of prostaglandin endoperoxides from arachadonic acid in the endothelium, specifically $\mathrm{PGI}_{2}$, stimulates adenylyl cyclase to convert adenosine triphosphate (ATP) to cyclic adenosine monophosphate (cAMP), which also facilitates pulmonary vasodilatation. ${ }^{[4,6]}$ Phosphodiesterase-3 (PDE3) increases the availability of cAMP. Prostaglandins decrease PVR less than does $\mathrm{NO}^{[4]}$

\section{Aetiology and pathophysiology}

When there is failure of the normal transition to extra-uterine life, with the persistence of increased PVR, PPHN occurs. Hypoxia, acidosis and hypercarbia cause vasoconstriction, and play an important role in the underlying pathogenesis. ${ }^{[0]}$

The causes of PPHN can be classified into four groups: underdevelopment, maldevelopment, maladaptation and intrinsic obstruction (Table 1). ${ }^{[3,4,6]}$

Meconium aspiration syndrome (MAS) is the most common cause of PPHN. ${ }^{[4,6]}$ Meconium-stained liquor occurs in $5-24 \%$ of normal pregnancies, and of these 5\% will develop MAS. Meconium causes airway obstruction, inactivation of surfactant and chemical pneumonitis, owing to the release of proinflammatory cytokines. The resultant decreased ventilation/perfusion ratio, with hypoxaemia and hypercarbia, may lead to PPHN. ${ }^{[3]}$

Idiopathic or 'black-lung' PPHN occurs in $20-25 \%$ of cases, with 'black lung' referring to the paucity of pulmonary vascularity. ${ }^{[3,4,6,8]}$ There is an absence of parenchymal lung disease, as the underlying problem is vascular smooth muscle hyperplasia of the normally muscle-free arteries. A questionable association with antenatal use of non-steroidal anti-inflammatory drugs and SSRIs exists. ${ }^{[12]}$

Congenital diaphragmatic hernia is associated with lung hypoplasia and the decreased cross-sectional area of the pulmonary vascular bed. Lung damage is often exacerbated by volutrauma, hyperoxia and mechanical ventilation. ${ }^{[6]}$ 
Table 1. Pathophysiology of PPHN ${ }^{[3,4,6]}$

\begin{tabular}{|c|c|c|c|c|}
\hline & Underdevelopment & Maldevelopment & Maladaptation & Intrinsic obstruction \\
\hline Pathology & Decreased vascular growth & Abnormal vascular structure & $\begin{array}{l}\text { Normal vasculature with } \\
\text { hypoxia induced vasospasm }\end{array}$ & $\begin{array}{l}\text { High viscosity resulting in } \\
\text { intravascular obstruction of } \\
\text { pulmonary arteries }\end{array}$ \\
\hline Examples & $\begin{array}{l}\text { Pulmonary hypoplasia: } \\
\text { - CDH } \\
\text { - Oligohydramnios } \\
\text { - Renal agenesis } \\
\text { - Rare causes, e.g. alveolar } \\
\text { capillary dysplasia }\end{array}$ & $\begin{array}{l}\text { Idiopathic/ } \\
\text { primary PPHN } \\
\text { Chronic fetal hypoxia } \\
\text { Fetal anaemia } \\
\text { Premature closure of ductus } \\
\text { arteriosus }\end{array}$ & $\begin{array}{l}\text { Asphyxia } \\
\text { Parenchymal diseases: } \\
\text { - MAS } \\
\text { - RDS } \\
\text { - Sepsis/pneumonia }\end{array}$ & Polycythaemia, e.g. IDM \\
\hline
\end{tabular}

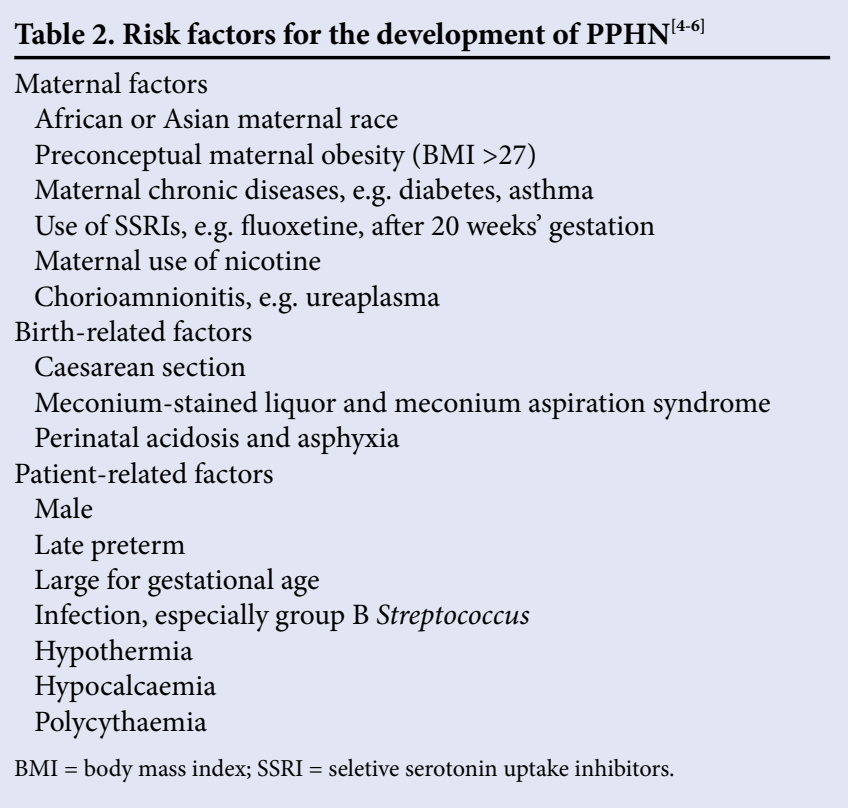

\section{Table 3. Echocardiographic diagnosis of $\mathrm{PPHN}^{[3-5,9,10]}$}

Exclude underlying cardiac abnormalities

To assist therapeutic decisionabrom making

TR jet velocity

To calculate RV pressure with modified Bernoulli equation

Direction of ductal shunting Identify right-to-left shunting

Alignment of the interventricular Rough indication of pulmonary septum
Rounded: PAP $<50 \%$ of systemic pressure

Flattened: PAP is $50-100 \%$ of systemic pressure Bows into the left ventricle: PAP exceeds systemic pressure

$\mathrm{TR}=$ tricuspid regurgitation; $\mathrm{RV}=$ right ventricle; $\mathrm{PAP}=$ pulmonary artery pressure

$\mathrm{PH}$ can occur in premature infants, with one-third of patients with bronchopulmonary dysplasia (BPD) having an underlying diagnosis of $\mathrm{PH}$. The combination of BPD and $\mathrm{PH}$ is associated with a poor outcome. $^{[3,6,8]}$

Congenital cardiac disease, such as total anomalous pulmonary venous return and hypoplastic left heart syndrome, may also present with PPHN. ${ }^{[4]}$

\section{Table 4. Diagnosis of PPHN}

\begin{tabular}{|c|c|c|}
\hline \multirow[t]{3}{*}{$\begin{array}{l}\text { Pre- and post- } \\
\text { ductal saturation }\end{array}$} & $\begin{array}{l}\text { Differential } \\
\text { cyanosis }^{[3,5,6,10]}\end{array}$ & $\begin{array}{l}\text { Pre-ductal saturation } \\
5-10 \% \text { higher than } \\
\text { post-ductal }\end{array}$ \\
\hline & Labile hypoxaemia $^{[3]}$ & $\begin{array}{l}\text { Marked change in } \\
\text { oxygen saturation with } \\
\text { minimal or no changes } \\
\text { in ventilator settings }\end{array}$ \\
\hline & $\begin{array}{l}\text { Disproportionate } \\
\text { hypoxaemi }^{[3,6]}\end{array}$ & $\begin{array}{l}\text { Hypoxaemia not } \\
\text { correlating with the } \\
\text { amount of parenchymal } \\
\text { disease seen on CXR }\end{array}$ \\
\hline $\mathrm{CXR}^{[4,10]}$ & \multicolumn{2}{|c|}{ Identify underlying parenchymal disease } \\
\hline $\begin{array}{l}\text { Complete blood } \\
\text { count }^{[4]}\end{array}$ & \multicolumn{2}{|c|}{ Diagnose infection and/or polycythaemia } \\
\hline $\begin{array}{l}\text { Serum glucose } \\
\text { and calcium }\end{array}$ & \multicolumn{2}{|c|}{ Underlying metabolic causes } \\
\hline $\mathrm{BNP}^{[3-6]}$ & \multicolumn{2}{|c|}{$\begin{array}{l}\text { Correlates with TR jet } \\
\text { Monitor response to treatment } \\
\text { Not routinely used }\end{array}$} \\
\hline
\end{tabular}

\section{Risk factors}

Several risk factors have been identified, including an unfavourable perinatal fetal environment which, in combination with certain epigenetic factors, may play a role in the expression of genes involved in the regulation of perinatal pulmonary circulation (Table 2). ${ }^{[2]}$

\section{Diagnosis}

PPHN presents in the first 24 hours of life. The classic clinical presentation includes respiratory distress, cyanosis, hypoxaemia and acidosis. ${ }^{[5]}$ The echocardiogram is the gold standard for the diagnosis of PPHN (Table 3). ${ }^{[3-5,9]}$

Although the echocardiogram is the gold standard for the diagnosis of PPHN, it is often not available in resource-limited settings, therefore other special investigations are of critical importance (Table 4). ${ }^{[13]}$ The traditional comprehensive structural and functional echocardiogram performed by cardiologists can be supplemented by training neonatologists to perform a targeted neonatal echocardiogram (TnEcho) to expedite diagnosis of PPHN and to monitor the response to therapy. ${ }^{[14]}$

\section{Severity of PPHN}

The severity of PPHN can be calculated using the oxygenation index (Table 5). ${ }^{[3]}$ 
Table 5. Classification of PPHN severity ${ }^{[3]}$

\begin{tabular}{|c|c|}
\hline Severity & $\mathrm{OI}^{x^{+}}$ \\
\hline Mild & $\leq 15$ \\
\hline Moderate & $>15-25$ \\
\hline Severe & $25-40$ \\
\hline Very severe & $>40$ \\
\hline \multicolumn{2}{|c|}{$\begin{array}{l}\mathrm{OI}=\text { oxygenation index; } \mathrm{MAP}=\text { mean airway pressure in } \mathrm{cmH}_{2} \mathrm{O} ; \mathrm{FiO}_{2}=\text { fraction } \\
\text { of inspired oxygen; } \mathrm{PaO}_{2}=\text { partial pressure of oxygen in } \mathrm{mmHg} ; \mathrm{OSI}=\text { oxygenation } \\
\text { saturation index. }\end{array}$} \\
\hline \multicolumn{2}{|c|}{$\begin{array}{l}{ }^{*} \mathrm{OI}=\mathrm{MAP} \times \mathrm{FiO}_{2} \times 100 / \mathrm{PaO}_{2} . \\
{ }^{\dagger} \mathrm{OI}=\mathrm{OSI} \times 2 ; \mathrm{OSI}=\mathrm{MAP} \times \mathrm{FiO}_{2} \times 100 / \text { pre-ductal saturation (no intravenous } \\
\text { access required) }\end{array}$} \\
\hline
\end{tabular}

Table 6. Recommendations for use of $\mathrm{iNO}^{[3,4,6]}$

\begin{tabular}{ll}
\hline Starting dose & $20 \mathrm{ppm}$ \\
Consider & $\mathrm{FiO}_{2}<60 \%$ \\
weaning when & $\mathrm{PaO}_{2}>60 \mathrm{mmHg}(>8 \mathrm{kPa})$ \\
& $\begin{array}{l}\text { Preductal saturation }>90 \% \\
\text { Above maintained for }>60 \text { minutes }\end{array}$ \\
Weaning & Wean by 5 ppm every $2-4$ hours till 5 ppm is reached \\
procedure & Then wean by 1 ppm every $2-4$ hours \\
Contra- & Hypoplastic left heart \\
indications & Interrupted aortic arch \\
ppm = parts per million.
\end{tabular}

\section{Management \\ General management}

The first-line management includes ventilation, oxygenation, maintaining systemic blood pressure and maintaining homeostasis. ${ }^{[10]}$ Stabilisation, establishing venous access and treating the underlying cause are critically important.

\section{Supportive care}

Hypothermia, acidosis, polycythaemia, hypoglycaemia, hypocalcaemia and hypomagnesaemia should be corrected appro-priately. ${ }^{[3,10]}$ Correction of acidosis with controlled alkalosis using an alkali infusion and hyperventilation is no longer advocated due to the association with sensorineural hearing loss and impaired cerebral perfusion. ${ }^{[3,10]}$

Minimal handling and judicious sedation is advised to avoid labile hypoxaemia. Antimicrobial therapy should be initiated if underlying infection is suspected. ${ }^{[6]}$

\section{Mechanical ventilation and oxygenation}

Oxygen is a pulmonary vasodilator; however, hyperoxia and ventilation with $100 \%$ oxygen has been associated with a reduced response to NO in experimental lamb models. ${ }^{[3,4]}$ The aim of mechanical ventilation should be to maintain a $\mathrm{PaCO}_{2}$ of $40-60 \mathrm{mmHg}(5.3-8.0 \mathrm{kPa})$ and $\mathrm{PaO}_{2}$ of $60-90 \mathrm{mmHg}(8-12 \mathrm{kPa})$ by using gentle ventilation to optimise lung volume. ${ }^{[4,5]}$ High-frequency oscillatory ventilation (HFOV) can minimise lung injury, but has not been proven to have a clear benefit over conventional ventilation, except when used in combination with inhaled $\mathrm{NO}$ (iNO) in the treatment of MAS ${ }^{[4,5,15]} \mathrm{HFOV}$ is recommended if peak inspiratory pressures (PIP) of $>28 \mathrm{cmH}_{2} \mathrm{O}$ or tidal volumes $>6 \mathrm{~mL} / \mathrm{kg}$ are required to maintain $\mathrm{PaCO}_{2}<60 \mathrm{mmHg}(<8 \mathrm{kPa}) .{ }^{[3]}$

\section{Surfactant}

In patients with MAS or pneumonia, surfactant may reduce the need for extracorporeal membrane oxygenation (ECMO), but does not reduce the duration of ventilation, length of the hospital stay or incidence of complications. ${ }^{[4,5]}$ Prior to giving the surfactant, adequate recruitment of lung volume should be prioritised. ${ }^{[4,5]}$ The greatest benefit was seen when administered at an OI of $15-25 .^{[3,6]}$ Dosages of $50-200 \mathrm{mg} / \mathrm{kg}$ may be used up to four times in the first 24 hours. ${ }^{[16]}$ The use of a surfactant in $\mathrm{CDH}$ is not recommended, unless there is clear evidence of surfactant deficiency, and then only $50 \%$ of the dose should be given because of the underlying pulmonary hypoplasia. ${ }^{[3]}$

\section{Management of systemic hypotension}

Systemic hypotension should be managed with fluids, vasopressors and inotropes. The optimal blood pressure (BP) has not been determined in a randomised controlled trial (RCT), and should therefore be maintained at the normal value for the gestational age. ${ }^{[5,6]}$ Supraphysiologic BP ought to be avoided, as it may add to ventricular strain and increase endothelial dysfunction by increasing shear stress in the constricted pulmonary circuit. ${ }^{[3]}$

Inotropic support should be considered early, as decreased systemic BP exacerbates right-to-left shunting and worsens hypoxaemia. ${ }^{[3,10]}$ Dopamine is commonly used, but at doses $>10 \mu \mathrm{g} / \mathrm{kg} /$ min it is not selective to systemic vasculature and may increase the PVR.${ }^{[17]}$ Dobutamine increases cardiac output and has limited effects on systemic pressure. ${ }^{[17]}$ Norepinephrine is effective in improving oxygenation and improving systemic BP, and in newborn lambs was associated with improved postnatal adaptation and significantly decreased oxygen requirement. ${ }^{[17]}$ Vasopressin and hydrocortisone may also be considered. ${ }^{[17]}$

\section{Pulmonary vasodilators Inhaled NO}

iNO is a potent and selective pulmonary vasodilator that leads to improved oxygenation and reduced need for ECMO by stimulating sGC activity to increase cGMP, a second messenger in the vasodilation pathway. ${ }^{[4,8,15]}$ The use of iNO was FDA approved in 1999 for term and near-term infants with PPHN, especially when the OI is greater than 25. ${ }^{[3,6]}$ The Neonatal Inhaled Nitric Oxide Study (NINOS) determined that the most effective starting dose of iNO is $20 \mathrm{ppm}$, and response should be seen within 30 - 60 minutes with an increase in $\mathrm{PaO}_{2}$ of $53 \mathrm{mmHg}(8.6 \mathrm{kPa})$ or a decrease in OI of $15 .^{[4,5,18,19]}$ The use of iNO has significantly reduced the mortality of PPHN; however, $\sim 40 \%$ of patients will not respond to iNO. ${ }^{[2,6,10]}$ Failure to respond to $20 \mathrm{ppm}$ is rarely followed by a response at a higher dosage ${ }^{[8,18]}$ The American Academy of Pediatrics (AAP) recommends the use of ECMO in non-responders. ${ }^{[20]}$ Methaemoglobinaemia and increased nitrogen dioxide are known side-effects that occur more frequently at dosages greater than $20 \mathrm{ppm} .{ }^{[3,4]}$ In patients with $\mathrm{CDH}$, iNO can be attempted early with optimal ventilation and recruitment, but should be discontinued if no improvements are seen. ${ }^{[21]}$

iNO requires gradual weaning to avoid rebound $\mathrm{PH}$ (Table 6). The rebound phenomenon may appear even in patients who did not show any improvement on iNO initially.

In patients with PPHN refractory to iNO, ensure adequate lung recruitment, repeat echocardiogram and consider alternative treatments. ${ }^{[2]}$

\section{Sildenafil}

Sildenafil is a PDE5 inhibitor, which results in increased availability of cGMP, and subsequent selective reduction in PVR $\cdot^{[3-5,8,22]}$ Increased PDE5 activity was documented in animal models with PPHN. ${ }^{[2]}$ Enteral sildenafil, dose range $1-3 \mathrm{mg} / \mathrm{kg}$ every 6 hours, reduced mortality in resource-limited settings where iNO is not available and reduced rebound $\mathrm{PH}$ after the withdrawal of iNO. ${ }^{[4-6,13,22-24]} \mathrm{A}$ Cochrane review recommended this as a significant alternative for PPHN treatment when iNO is not available. ${ }^{[25]}$ 
Table 7. Alternative drug treatments for PPHN

\begin{tabular}{|c|c|c|}
\hline Drug & $\begin{array}{l}\text { Effects/mechanism } \\
\text { of action }\end{array}$ & Evidence/recommendation \\
\hline $\begin{array}{l}\text { Inhaled } \mathrm{PGI}_{2} \text {, e.g. iloprost, } \\
\text { treprostinil }{ }^{[4,6,8,23,29]}\end{array}$ & $\begin{array}{l}\text { Activates adenylyl cyclase } \\
\text { Increases cAMP }\end{array}$ & $\begin{array}{l}\text { Cannot be recommended for } \\
\text { routine use }\end{array}$ \\
\hline Magnesium sulphate $\mathrm{e}^{[4,5,30]}$ & $\begin{array}{l}\text { Reduce PAP } \\
\text { Systemic hypotension }\end{array}$ & $\begin{array}{l}\text { Observational data only } \\
\text { More studies recommended }\end{array}$ \\
\hline Bosentan $^{[3-5,23]}$ & $\begin{array}{l}\text { Non-selective endothelin } \\
\text { receptor antagonist }\end{array}$ & $\begin{array}{l}\text { Efficacy in RCT where iNO } \\
\text { not available }\end{array}$ \\
\hline $\begin{array}{l}\text { Sitaxentan } \\
\text { Ambrisentan }^{[4]}\end{array}$ & $\begin{array}{l}\text { Selective } \mathrm{ET}_{\mathrm{A}} \text { receptor } \\
\text { antagonists }\end{array}$ & More studies needed \\
\hline Furegulate sodium ${ }^{[5]}$ & $\begin{array}{l}\text { Thromboxane synthase } \\
\text { inhibitor } \\
34 \% \text { reduction in PVR }\end{array}$ & Animal studies only \\
\hline Adenosine $e^{[2,5]}$ & eNOS agonist & Case series only \\
\hline Antenatal betamethasone $\mathrm{e}^{[3,6]}$ & $\begin{array}{l}\text { Improved pulmonary artery } \\
\text { relaxation } \\
\text { Reduced oxidative stress }\end{array}$ & Animal studies \\
\hline Postnatal systemic steroids ${ }^{[3,6,23]}$ & $\begin{array}{l}\text { Reduced hospital stay and } \\
\text { oxygen dependence in MAS }\end{array}$ & $\begin{array}{l}\text { Not routinely recommended } \\
\text { More research needed, } \\
\text { especially in limited-resource } \\
\text { settings }\end{array}$ \\
\hline Postnatal hydrocortisone $\mathrm{e}^{[3,6,23]}$ & $\begin{array}{l}\text { Improved oxygenation } \\
\text { Increased cGMP } \\
\text { Reduced ROS } \\
\text { Increased SOD }\end{array}$ & $\begin{array}{l}\text { Animal studies } \\
\text { Case reports* }\end{array}$ \\
\hline Recombinant human SOD ${ }^{[6]}$ & - & Animal studies only \\
\hline Apocynin $^{[31]}$ & $\begin{array}{l}\text { NADPH oxidase inhibitor } \\
\text { Improved oxygenation } \\
\text { Reduced vascular dysfunction }\end{array}$ & Animal studies only \\
\hline
\end{tabular}

In the treatment of PH secondary to BPD, sildenafil at doses of $0.5 \mathrm{mg} / \mathrm{kg}$ every 8 hours to $2 \mathrm{mg} / \mathrm{kg}$ every 6 hours is considered safe and effective, and contributes to improved survival at 12 months. ${ }^{[23,26]}$

\section{Milrinone}

Milrinone is a PDE3 inhibitor that leads to increased availability of cAMP, with resultant positive inotropic effects, peripheral vasodilatation, left ventricular afterload reduction and increased myocardial contractility. ${ }^{[3,5,8,23]}$ There are case reports of improved oxygenation in cases of PPHN refractory to $\mathrm{iNO}^{[3,23]}$ but there are also reports of an increased incidence of intracranial haemorrhages. ${ }^{[27]}$ Safety and efficacy is unknown, and therefore it is recommended for use only within randomised controlled trials (RCTs) ${ }^{[28]}$

\section{Other drug therapies}

Other promising treatment modalities include $\mathrm{PGI}_{2}$, magnesium sulphate, bosentan, adenosine, steroids and apocynin, but there is insufficient evidence to recommend any for routine or combination use (Table 7).

\section{Extracorporeal membrane oxygenation}

Although ECMO is viewed as the ultimate rescue therapy in developed countries, it is not freely available in lowresource countries, therefore rendering its usefulness in developing countries questionable. ${ }^{[3,6]}$

\section{Special categories}

Special consideration should be given when treating a patient with PPHN and perinatal asphyxia, as the treatment of PPHN may affect cerebral blood flow. ${ }^{[3,32]}$ Inhaled NO does not significantly alter neurodevelopmental outcome. ${ }^{[3,32]}$ The effects of moderate therapeutic hypothermia at $33.5^{\circ} \mathrm{C}$ for 72 hours does not result in a significant increase in PPHN. ${ }^{[3]}$ There are case reports that preceding hypoxia requiring $\mathrm{FiO}_{2}>50 \%$ and/or iNO may be associated with exacerbation of PPHN with hypothermia and/or rewarming. ${ }^{[3]}$ Fluid boluses are not recommended in these patients, unless there is hypovolaemia, as it may increase cerebral oedema. ${ }^{[3,32]}$

\section{Outcome}

The long-term neurological outcome is largely determined by the underlying condition. Neurodevelopmental impairment has been reported in up to $25 \%$ at 2 years of age and hearing impairment in $23 \%{ }^{[3,5]}$

At school age, there were $24 \%$ persistent respiratory problems, $60 \%$ abnormal chest $\mathrm{X}$-rays, 6\% sensorineural hearing loss, 9\% IQ $<90$, and $7 \%$ IQ $70-84 .{ }^{[3]}$ These infants require long-term multidisciplinary follow-up.

\section{Conclusion}

PPHN is an acute neonatal disorder with complex underlying pathophysiology, which has a high mortality rate despite several advances in the management thereof. Inhaled NO is a safe and effective clinical strategy in the majority of patients, but is not always available in resource-limited settings. Oral sildenafil is a relatively safe alternative option in these settings. Newer drugs need to be studied before any recommendations can be made for routine use.

\section{References}

1. Gersony WM, Duc GV, Sinclair JC. "PFC" syndrome (persistence of fetal circulation). Circulation 1969;40(suppl 1):3-87.

2. Distefano G, Sciacca P. Molecular physiopathogenetic mechanisms and development of new potential therapeutic strategies in persistent pulmonary hypertension of the newborn. Ital J Pediatr 2015;41(1):6. http:// dx.doi.org/10.1186/s13052-015-0111-0

3. Sharma V, Berkelhamer S, Lakshminrusimha S. Persistent pulmonary hypertension of the newborn. Matern Health Neonatol Perinato 2015;1:14. http://dx.doi.org/10.1186/s40748-0150015-4

4. Puthiyachirakkal M, Mhanna MJ. Pathophysiology, management, and outcome of persistent pulmonary hypertension of the newborn: A clinical review. Front Pediatr 2013;1:23. http:/ dx.doi.org/10.3389/fped.2013.00023

5. Bendapudi P, Rao GG, Greenough A. Diagnosis and management of persistent pulmonary hypertension of the newborn. Paediatr Respir Rev 2015;16(3):157-161. http://dx.doi.org/10.1016/j. prrv. 2015.02 .001

6. Nair J, Lakshminrusimha S. Update on PPHN: Mechanisms and treatment. Semin Perinato 2014;38(2):78-91. http://dx.doi.org/10.1053/j. semperi.2013.11.004

7. Jain A, McNamara PJ. Persistent pulmonary hypertension of the newborn: Advances in diagnosis and treatment. Semin Fetal Neonatal Med 2015:20(4):262-271. http://dx.doi. org/10.1016/j.siny.2015.03.001

8. Porta NFM, Steinhorn RH. Pulmonary vasodilator therapy in the NICU: Inhaled nitric oxide, sildenafil, and other pulmonary vasodilating agents. Clin Perinatol 2012;39(1):149-164. http:// dx.doi.org/10.1016/j.clp.2011.12.006

9. Aggarwal S, Natarajan G. Echocardiographic correlates of persistent pulmonary hypertension of the newborn. Early Hum Dev 2015;91(4):285-289. http://dx.doi.org/10.1016/j. earlhumdev.2015.02.008

10. Bendapudi P, Barr S. Diagnosis and management of pulmonary hypertension of the newborn. Paediatr Child Health 2014;24(1):12-16. http:// dx.doi.org/10.1016/j.paed.2013.05.021

11. Hillman NH, Kallapur SG, Jobe AH. Physiology of transition from intrauterine to extrauterine life. Clin Perinatol 2012;39(4):769-783. http://dx.doi. org/10.1016/j.clp.2012.09.009 
12. Huybrechts KF, Bateman BT, Palmsten K, et al. Antidepressant use late in pregnancy and risk of persistent pulmonary hypertension of the newborn. JAMA 2015;313(21):2142-2151. http://dx.doi.org/10.1097/01.ogx.0000472158.66771.3e

13. Engelbrecht AL. Sildenafil in the management of neonates with PPHN: A rural regional hospital experience. S Afr J Child Health 2008;2(4):166-169.

14. El-Khuffash A, Herbozo C, Jain A, Lapointe A, McNamara PJ. Targeted neonatal echocardiography (TnECHO) service in a Canadian neonatal intensive care unit: A 4-year experience. J Perinatol 2013;33(9):687-690. http:// dx.doi.org/10.1038/jp.2013.42

15. Kinsella JP, Abman SH. Inhaled nitric oxide and high frequency oscillatory ventilation in persistent pulmonary hypertension of the newborn. Eur J Pediatr ventilation in persistent pulmonary hypertension of the newborn. Eur J Pediatr
1998;157(Suppl 1):S28-30. http://dx.doi.org/10.1378/chest.114.1_supplement.100s 1998;157(Suppl 1):S28-30. http://dx.doi.org/10.1378/chest.114.1_supplement.100s
6. Ullah A. Surfactant therapy in meconium aspiration syndrome (MAS). New Indian J OBGYN 2014;1(1):24-29. http://journal.barpetaogs.co.in/pdfs/1124.pdf

17. Tourneux P, Rakza T, Bouissou A, Krim G, Storme L. Pulmonary circulatory effects of norepinephrine in newborn infants with persistent pulmonary hypertension. J Pediatr 2008;153(3):345-349. http://dx.doi.org/10.1016/j. ipeds.2008.03.007

18. The Neonatal Inhaled Nitric Oxide Study Group. Inhaled nitric oxide in fullterm and nearly full-term infants with hypoxic respiratory failure. N Engl J Med 1997;336(9):597-604. http://dx.doi.org/10.1056/nejm199702273360901

19. Finer NN, Barrington KJ. Nitric oxide for respiratory failure in infants born at or near term. Cochrane Database Syst Rev 2001;Issue 4:Art. no. CD000399. http://dx.doi.org/10.1002/14651858.cd000399

20. Lakshminrusimha S, Keszler M. Persistent pulmonary hypertension of the newborn. Neoreviews 2015;16(12):e680-692. http://dx.doi.org/10.1542/neo.1612-e680

21. Pierro M, Thébaud B. Understanding and treating pulmonary hypertension in congenital diaphragmatic hernia. Semin Fetal Neonatal Med 2014;19(6):357363. http://dx.doi.org/10.1016/j.siny.2014.09.008

22. Michelakis ED, Tymchak W, Noga M, et al. Long-term treatment with oral sildenafil is safe and improves functional capacity and hemodynamics in patients with pulmonary arterial hypertension. Circulation 2003;108(17):20662069. http://dx.doi.org/10.1161/01.cir.0000099502.17776.c2

23. Lakshminrusimha S, Mathew B, Leach CL. Pharmacologic strategies in neonatal pulmonary hypertension other than nitric oxide. Semin Perinatol 2016;40(3):160-173. http://dx.doi.org/10.1053/j.semperi.2015.12.004
24. Baquero H, Soliz A, Neira F, Venegas ME, Sola A. Oral sildenafil in infants with persistent pulmonary hypertension of the newborn: A pilot randomised blinded study. Pediatrics 2006;117(4):1077-1083. http://dx.doi.org/10.1542/ peds.2005-0523

25. Shah PS, Ohlsson A. Sildenafil for pulmonary hypertension in neonates. In: Shah PS, ed. Reviews. Chichester, UK: Wiley-Blackwell, 2011. http://dx.doi. org/10.1002/14651858.cd005494.pub3

26. Wardle AJ, Wardle R, Luyt K, Tulloh R. The utility of sildenafil in pulmonary hypertension: A focus on bronchopulmonary dysplasia. Arch Dis Child 2013:98(8):613-617. http://dx doi.org/10.1136/archdischild-2012-303333

27. James AT, Corcoran JD, McNamara PJ, Franklin O, El-Khuffash AF. The effect of milrinone on right and left ventricular function when used as a rescue therapy for term infants with pulmonary hypertension. Cardiol Young 2016;35(11):913918. http://dx.doi.org/10.1017/s1047951114002698

28. Bassler D, Kreutzer K, McNamara P, Kirpalani H. Milrinone for persistent pulmonary hypertension of the newborn. Cochrane Database Syst Rev 2010;(11):CD007802. http://dx.doi.org/10.1002/14651858.CD007802.pub2

29. Kelly LK, Porta NFM, Goodman DM, Carroll CL, Steinhorn RH. Inhaled prostacyclin for term infants with persistent pulmonary hypertension refractory to inhaled nitric oxide. J Pediatr 2002;141(6):830-832. http://dx.doi. org/10.1067/mpd.2002.129849

30. Ho JJ, Rasa G. Magnesium sulfate for persistent pulmonary hypertension of the newborn. Cochrane Database Syst Rev 2007;(3):CD005588. http://dx.doi. org/10.1002/14651858. CD005588.pub2

31. Wedgwood S, Lakshminrusimha S, Farrow KN, et al. Apocynin improves oxygenation and increases eNOS in persistent pulmonary hypertension of the newborn. Am J Lung Cell Mol Physiol 2012;302(6):L616-626. http://dx.doi. org/10.1152/ajplung.00064.2011

32. Lapointe A, Barrington KJ. Pulmonary hypertension and the asphyxiated newborn. J Pediatr 2011;158(2 Suppl):e19-24. http://dx.doi.org/10.1016/j. jpeds.2010.11.008

Accepted 20 July 2016. 